\title{
The adherence of verocytotoxin-producing Escherichia coli to rabbit intestinal cells
}

\author{
S. ASHKENAZI, M. LAROCCO*, B. E. MURRAY $\dagger$ and T. G. CLEARY $\ddagger$
}

Department of Pediatrics, Beilinson Medical Center, Petah Tiqva, Tel Aviv University Sackler School of Medicine, Israel, "Department of Pathology and Laboratory Medicine and Divisions of Infectious Diseases, and Departments of $\dagger$ Medicine and $\ddagger$ Pediatrics, University of Texas Medical School, Houston, Texas, USA

\begin{abstract}
Summary. Verocytotoxin-producing Escherichia coli (VTEC) have been recognised recently as an important cause of human disease. The adherence of VTEC to rabbit intestinal tract and the relationship between adherence and other virulence traits were studied. Twenty clinical isolates of VTEC (O157: $\mathrm{H} 7$ and other serotypes) and a control, commensal E. coli strain, were examined. Bacteria were evaluated for the presence of surface fimbriae, plasmid profile and hybridisation with a $3.4 \mathrm{~kb}$ DNA probe derived from the 60-MDa plasmid of such strains. Adherence was determined by electronmicroscopy and quantitatively with radiolabelled bacteria. Of the VTEC strains, $12(60 \%)$ had surface fimbriae; all $\mathrm{O} 157: \mathrm{H} 7$ and 10 $(70 \%)$ of 14 of the non-O157:H7 strains hybridised with the probe. No isolate was negative for both of these virulence traits and there was no correlation between their presence. The plasmid profiles varied among the strains, with no correlation to virulence traits. The adherence of VTEC strains differed significantly, ranging from 0.3 to 34.0 bacteria/intestinal cell. The mean adherence of fimbriate strains was greater than that of non-fimbriate strains (3.9 versus 2.7 bacteria/cell), although marked variability was noted in both groups. This study showed that VTEC strains differed markedly in their adherence capability and that neither the presence of fimbriae nor hybridisation with the $3 \cdot 4-\mathrm{kb}$ probe was essential for adherence. Several distinct mechanisms probably play a role in VTEC adherence.
\end{abstract}

\section{Introduction}

Cytotoxin-producing Escherichia coli have been recognised as a cause of watery diarrhoea, haemorrhagic colitis and the haemolytic uraemic syndrome (HUS).$^{1-3}$ Prospective studies have shown that these organisms are a major cause of bacterial diarrhoea in certain areas ${ }^{4,5}$ and are related to $75-94 \%$ of HUS cases. $^{5,6}$ Although E. coli serotype $0157: \mathrm{H} 7$ was implicated initially, it has been shown that various other serotypes are involved. These bacteria are often referred to as verocytotoxin-producing $E$. coli (VTEC), or enterohaemorrhagic E. coli, ${ }^{2,7}$ and produce high levels of cytotoxins.

In addition to toxin production, adherence of bacteria to the intestinal mucosa is considered to be a critical initial step in pathogenesis. ${ }^{8}$ Attachment prevents expulsion of the micro-organisms by the peristaltic clearing mechanisms and enables colonisation of the intestinal mucosa with effective toxin delivery. Adherence of VTEC to intestinal mucosa has been demonstrated in several animal studies. ${ }^{9-13}$

The virulence traits that mediate VTEC adherence are unclear, with conflicting and confusing data. Some reports have suggested that bacterial surface fimbriae were necessary for binding. ${ }^{12,14}$ Others have reported that surface structures other than fimbriae, ${ }^{15,16}$ such as outer-membrane constituents, ${ }^{17}$ mediated adherence and that many VTEC lacked surface fimbriae. ${ }^{18}$ The presence of a 60-MDa plasmid has been described as a virulence trait required for binding to intestinal mucosa, ${ }^{12,18,19}$ possibly by encoding bacterial fimbriae ${ }^{12}$ or other surface structures. ${ }^{16}$ A 3.4-kb HindIII fragment derived from this plasmid hybridised with most VTEC isolates but not with other strains ( $99 \%$ specificity). ${ }^{20}$ In contrast, the use of plasmid-cured derivatives of VTEC suggested that adherence to the human embryonic intestinal cell line INT $407^{21}$ and in gnotobiotic piglets ${ }^{22}$ did not depend on the $60-\mathrm{MDa}$ plasmid.

The reasons for these conflicting data are unclear. They may be related to true variability in the virulence traits of different VTEC strains. They may also be related, at least in part, to methodology, e.g., in many studies only a few strains, often only one or two, were studied, and only one of the virulence traits was examined. Determining adherence by morphological observations has advantages in terms of descriptive changes but is difficult to quantify and is subjective. 
The aim of this study was to examine the adherence of a number of serotypically distinct VTEC strains from different geographic locations by a quantitative, radiolabelled assay that has been described previously. ${ }^{23,24}$ Adherence was also confirmed morphologically by scanning electronmicroscopy. Plasmid profiles of the bacteria, hybridisation with the 3.4-kb DNA probe and the presence of surface fimbriae were determined. As expression of virulence traits often depends on growth conditions and other environmental factors, the strains were grown and examined simultaneously, under standard conditions.

\section{Materials and methods}

\section{Bacteria}

Clinical isolates of $E$. coli from patients with watery diarrhoea, haemorrhagic colitis or HUS (table I) were studied. E. coli serotype $\mathrm{O} 26: \mathrm{H} 11$ strain $\mathrm{H} 30$ was a reference strain described originally by Konowalchuk et al. ${ }^{7}$ E. coli serotype O157:H7 strain 212-2 and E. coli untypable: $\mathrm{H} 21$ strain 43-12 were isolated from our studies in Argentina. ${ }^{5}$ Serotyping of these strains was performed by R. Wilson at the $E$. coli Reference Center, Pennsylvania State University. E. coli serotype O157:H7 strains 987, E439, E670, E854 and E1057 were obtained from M. Osterholm, Minnesota Department of Public Health. E. coli strains 3047-86, 3030-86, 3007-85, 75-83, 3288-85, A9619-C, 3056-85, $3377-85,3143-85$ and $3153-86^{25}$ were kindly provided by N. Strockbine, Centers for Disease Control, Atlanta, GA. Strains CL37A1 and CL15A were kindly provided by M. Karmali, Toronto, Canada. ${ }^{6}$ E. coli serotype $\mathrm{O} 9: \mathrm{H} 4$, strain HS, a human faecal commensal that has been used as a negative control in many studies, ${ }^{14}$ was also examined.

Stock bacteria were stored in glycerol $10 \%$ in broth at $-70^{\circ} \mathrm{C}$. For the assay, bacteria were grown in $10 \mathrm{ml}$ of Penassay Broth (Difco) without aeration. Radiolabelled bacteria were prepared by adding ${ }^{3} \mathrm{H}$ thymidine $(1 \mathrm{mCi} / \mathrm{ml}, 25 \mu \mathrm{Ci} / \mathrm{mmol}$; ICN Radiochemicals, Irvine, CA, USA) $0.1 \mathrm{mCi} / 10 \mathrm{ml}$ of Penassay Broth. After growth overnight at $37^{\circ} \mathrm{C}$, bacteria were harvested by centrifugation $(8000 \mathrm{~g}$ for $10 \mathrm{~min})$ and washed twice in phosphate-buffered saline (PBS).

Cytotoxicity of cell-free extracts of the bacteria on $\mathrm{HeLa}$ cells was determined quantitatively as described previously. ${ }^{26}$ Neutralisation studies were performed by pre-incubation with antiserum against Shiga toxin, which also neutralises Shiga-like toxin-I (SLT-I), or antiserum against SLT- $\mathrm{II}^{26}$ to determine the type of toxin produced.

\section{DNA hybridisation studies and plasmid profiles}

Isolates were examined by colony hybridisation with several DNA probes. The presence of the structural genes for Shiga toxin, SLT-I and SLT-II were determined by hybridisation with the probes described by Newland and Neill. ${ }^{27}$ The 3.4-kb probe of the 60MDa plasmid was also used. ${ }^{20}$ Probes were extracted from low-temperature-gelling agarose and labelled by nick translation with ${ }^{32} \mathrm{P}$-labelled 5'-dCTP (Dupont, NEM Research Products, Boston, MA, USA). Bacterial colonies were transferred to Whatman 541 filter papers, lysed and hybridised under stringent conditions-formamide $50 \%$ at $42^{\circ} \mathrm{C}$ with $2 \times \mathrm{SSC}$ (SSC is $0.5 \mathrm{M} \mathrm{NaCl}$ containing $0.015 \mathrm{M}$ sodium citrate) for $18 \mathrm{~h}^{25}$ Appropriate positive and negative strains were placed on each filter. Plasmid DNA was prepared as described previously, ${ }^{28}$ separated by gel electrophoresis in agarose $0.7 \% \mathrm{w} / \mathrm{v}$, stained by ethidium bromide and visualised under ultraviolet light.

\section{Electronmicroscopy}

All isolates were negatively stained with phosphotungstic acid $2 \% \mathrm{w} / \mathrm{v}$ and examined by electronmicroscopy (Jeol $100 \mathrm{CX} 2$, Japan) for the presence of surface fimbriae. Scanning electronmicroscopy was performed essentially as described previously, ${ }^{24}$ to visualise the adherence of bacteria to intestinal mucosa. Intestinal sections, placed on Dot blot apparatus to get defined exposed surfaces, were incubated with bacteria $\left(0.2 \mathrm{ml} ; 6 \times 10^{9}\right.$ bacteria $/ \mathrm{ml}$ for $\left.45 \mathrm{~min}\right)$. After washing three times with PBS, the exposed areas were cut, fixed with glutaraldehyde $2 \%$ for $1 \mathrm{~h}$ and postfixed with osmium tetroxide $2 \%$ for $1 \mathrm{~h}$. Specimens were then dehydrated with ethanol, air-dried for $5 \mathrm{~min}$, treated with hexamethyldisilazane, sputter coated with gold and examined with a JSM-820 scanning electronmicroscope (Jeol).

\section{Preparation of isolated intestinal cells}

New Zealand White rabbits (Ray Nichols, Lumberton, TX, USA) were killed by intravenous injection of sodium pentothal and loops of the terminal ileum or proximal colon were obtained. After washing with saline, intestinal cells were released from these loops by treatment with solutions containing EDTA, citrate and dithiothreitol. ${ }^{23,25}$ Cells were suspended in $20 \mathrm{mM}$ morpholinoethane sulphonate (MES) buffer containing $140 \mathrm{mM} \mathrm{NaCl}$ and $1 \mathrm{mM} \mathrm{CaCl}_{2}$. The viability of the intestinal cells was monitored by trypan blue exclusion.

\section{Assay for bacterial adherence to intestinal cells}

A suspension of intestinal cells $\left(200 \mu 1,10^{7}\right.$ cells $\left./ \mathrm{ml}\right)$ was incubated with radiolabelled bacteria $(100 \mu \mathrm{l}$, $\left.6^{\prime} \times 10^{\circ} \mathrm{bacterial} / \mathrm{ml}\right)$ at $37^{\circ} \mathrm{C}$ in a rotating rack $(8 \mathrm{rpm})$ for $45 \mathrm{~min}$. The reaction was stopped by adding $2.5 \mathrm{ml}$ of saline and by centrifugation $(500 \mathrm{~g}, 5 \mathrm{~min})$ to sediment the intestinal cells. The supernate, which contained non-adherent bacteria, was discarded. The 
Table I. Characteristics of $E$. coli strains examined

\begin{tabular}{|c|c|c|c|c|}
\hline Strain no. & Serotype & Origin & Disease & Reference no. \\
\hline $3047-86$ & 026:H1l & Australia & $\mathrm{HC}$ & 25 \\
\hline H30 & $026: \mathrm{H} 11$ & Canada & D & 7 \\
\hline $43-12$ & UT:H21 & Argentina & HUS & 5 \\
\hline $3030-86$ & $0111: \mathrm{H} 8$ & $\begin{array}{l}\text { Idaho } \\
\text { la }\end{array}$ & $\mathrm{HC}$ & 25 \\
\hline $3007-85$ & 0111:NM & Nebraska & $\mathrm{HC}$ & 25 \\
\hline CL37A1 & $0111: \mathrm{H} 8$ & Canada & HUS & 6 \\
\hline $75-83$ & 0145:NM & S. Dakota & $\mathrm{HC}$ & 25 \\
\hline $3288-85$ & $0172: \mathrm{NM}$ & California & $\mathrm{HC}$ & 25 \\
\hline A9619-C & $045: \mathrm{H} 2$ & Michigan & $\mathrm{HC}$ & 25 \\
\hline $3056-85$ & 0121:H19 & Oklahoma & $\mathrm{HC}$ & 25 \\
\hline $3377-85$ & 04:NM & Georgia & $\mathrm{HC}$ & 25 \\
\hline $3143-85$ & 05:NM & England & $\mathrm{HC}$ & 25 \\
\hline $3153-86$ & 0125:NM & N. Carolina & $\mathrm{HC}$ & 25 \\
\hline CL15A & 0113:H21 & Canada & HUS & 6 \\
\hline 987 & $0157: \mathrm{H} 7$ & Minnesota & $\mathrm{HC}$ & $\ldots$ \\
\hline $212-2$ & $0157: \mathrm{H} 7$ & Argentina & $\mathrm{HC}$ & 5 \\
\hline E439 & 0157:H7 & Minnesota & $\mathrm{HC}$ & $\ldots$ \\
\hline E670 & 0157:H7 & Minnesota & $\mathrm{HC}$ & $\ldots$ \\
\hline E854 & $0157: H 7$ & Minnesota & $\mathrm{HC}$ & $\ldots$ \\
\hline E1057 & $0157: \mathrm{H} 7$ & Minnestoa & D & $\ldots$ \\
\hline HS & $09: \mathrm{H} 4$ & USA & Commensal & 14 \\
\hline
\end{tabular}

UT, untypable; NM, non-motile; HC, haemorrhagic colitis; HUS, haemolytic-uraemic syndrome; $\mathrm{D}$, diarrhoea.

intestinal cells were separated from remaining unattached bacteria by discontinuous density gradient centrifugation with Percoll (Sigma). ${ }^{23}$ The reliability of the separation procedure was repeatedly tested by counting the radioactivity of the cellular layer when no bacteria had adhered. The layer of intestinal cells with adherent bacteria was transferred to $3 \mathrm{ml}$ of scintillation fluid and counted for radioactivity.

\section{Statistical analysis}

All experiments were performed in duplicate and repeated at least twice. Analysis of variance was used to determine the significance of the differences among various groups of bacteria. Fisher's exact test was used to compare proportions.

\section{Results}

All 20 VTEC strains examined in this study produced high levels of cytotoxic activity. Neutral- isation studies and DNA hybridisation showed that nine strains produced SLT-I, five strains produced SLT-II and six strains produced both toxins.

\section{Presence of surface fimbriae}

Electronmicroscopy of negatively stained bacteria, that were grown and prepared simultaneously, showed surface fimbriae on 12 of the 20 strains (table II). Some bacteria had fimbriae that covered almost their whole surface; others were only partially covered (fig. 1).

\section{Plasmid profile and hybridisation with 3·4-kb probe}

Plasmid profiles of VTEC strains showed that they all possessed a 50-70 MDa plasmid. Profile of representative strains are shown in fig. 2. Most strains also had one or more smaller plasmids. Strains of serotype O157:H7 did not show similar plasmid profiles, nor

Table II. Presence of fimbriae, hybridisation with $3 \cdot 4-\mathrm{kb}$ DNA probe and adherence to rabbit ileal cells of VTEC strains

\begin{tabular}{|c|c|c|c|}
\hline $\begin{array}{l}\text { VTEC } \\
\text { strain no. }\end{array}$ & $\begin{array}{c}\text { Fimbriae* } \\
\text { (mean number } / \\
\text { cell) }\end{array}$ & $\begin{array}{l}\text { Hybridisation } \\
\text { with } 3 \cdot 4-\mathrm{kb} \\
\text { DNA probe }\end{array}$ & $\begin{array}{c}\text { Adherence } \\
\text { (mean number of } \\
\text { bacteria/cell) }\end{array}$ \\
\hline $3047-86$ & $>20$ & - & $0 \cdot 3$ \\
\hline H30 & - & + & $11 \cdot 3$ \\
\hline $43-12$ & $>20$ & - & 34.0 \\
\hline $3030-86$ & - & + & 2.9 \\
\hline $3007-85$ & 14 & + & $1 \cdot 0$ \\
\hline CL37A1 & 8 & - & 1.0 \\
\hline $75-83$ & - & + & $2 \cdot 3$ \\
\hline $3288-85$ & - & + & 0.9 \\
\hline A9619-C & - & + & $1 \cdot 0$ \\
\hline $3056-85$ & - & + & $2 \cdot 3$ \\
\hline $3377-85$ & - & + & 1.9 \\
\hline $3143-85$ & - & + & 0.9 \\
\hline $3153-86$ & $>20$ & - & $9 \cdot 3$ \\
\hline CL15A & 6 & + & $5 \cdot 1$ \\
\hline 987 & 12 & + & $10 \cdot 1$ \\
\hline $212-2$ & - & + & $2 \cdot 2$ \\
\hline E439 & - & + & $2 \cdot 8$ \\
\hline E670 & - & + & $4 \cdot 4$ \\
\hline E854 & 6 & + & $12 \cdot 6$ \\
\hline E1057 & - & + & $2 \cdot 3$ \\
\hline HS & 6 & - & $2 \cdot 1$ \\
\hline
\end{tabular}

*-, Non-fimbriate.

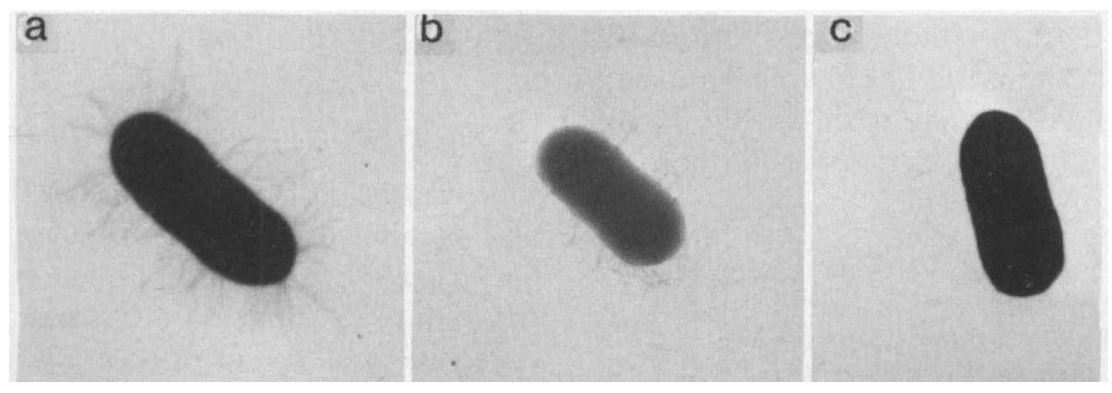

Fig. 1. Electronmicrographs of negatively stained VTEC strains : $\mathbf{a}$, fimbriae all over the surface of the bacteria; $\mathbf{b}$, fimbriae cover only part of the bacterial surface; $\mathbf{c}$, no surface fimbriae. 
C $123456789 \mathrm{c}$

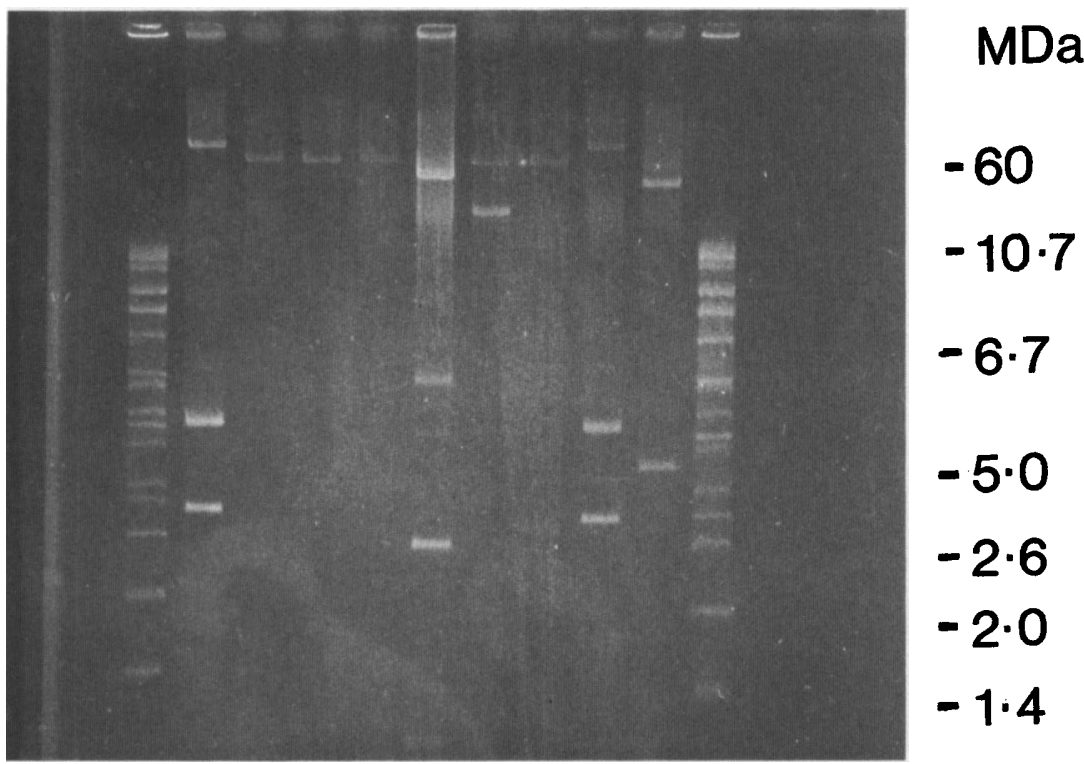

Fig. 2. Plasmid profiles of 11 VTEC strains. Plasmid DNA was separated in agarose $0.7 \%$ gel, stained by ethidium bromide and visualised under ultraviolet light. The strains shown are: 1, E. coli $43-12 ; 2, E$. coli $212-2 ; 3, E$. coli $\mathrm{E} 854 ; 4, E$. coli $\mathrm{E} 670 ; 5, E$. coli $\mathrm{H} 30 ; 6, E$. coli 987 ; 7, E. coli E1057; 8, E. coli E439; 9, E. coli 75-83; C shows the supercoiled DNA ladder, molecular size control.

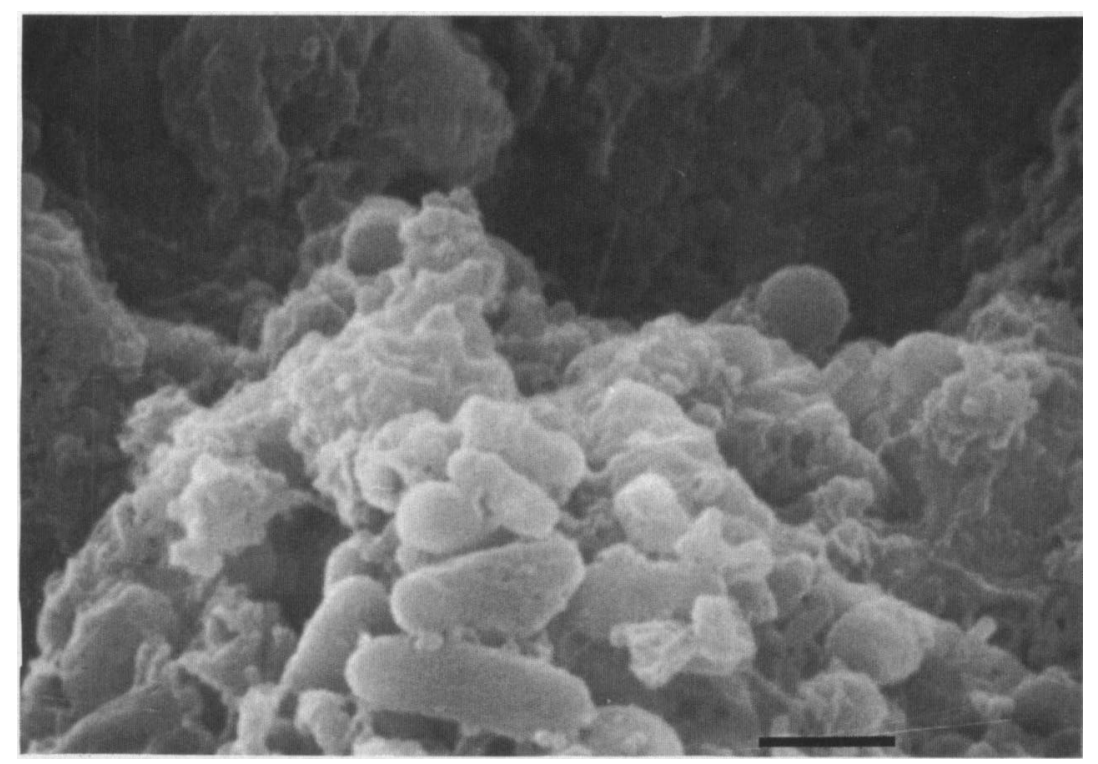

Fig. 3. Scanning electronmicrograph of adherence of E. coli strain 43-12 to rabbit ileum. Bacteria adhered avidly to the brush border surface with mild damage to the microvilli. Bar, $1 \mu \mathrm{m} ; \times 14000$.

were their profiles as a group distinct from those of VTEC strains of other serotypes. No correlation was noted between plasmid profile and virulence traits. Sixteen $(80 \%)$ of the strains (all six O157:H7 strains and $10(70 \%)$ of 14 of the non-O157:H7 strains) hybridised with the 3.4-kb DNA probe derived from the $60-\mathrm{MDa}$ adherence plasmid (table II). The difference was not statistically significant. There was no correlation between hybridisation with this probe and the presence of surface fimbriae. In fact, the strains that did not hybridise showed fimbriae and usually in a higher density than the strains that did hybridise.
Eleven strains were positive in the hybridisation assay but did not show surface fimbriae.

\section{Adherence of VTEC strains to intestinal cells}

Scanning electronmircoscopy showed that VTEC strains adhered to the brush border surface of the intestinal mucosa (fig. 3). Differences in the adherence of the various strains to intestinal surfaces were observed. They were determined precisely by the quantitative assay.

The optimal conditions for the radiolabelled assay 


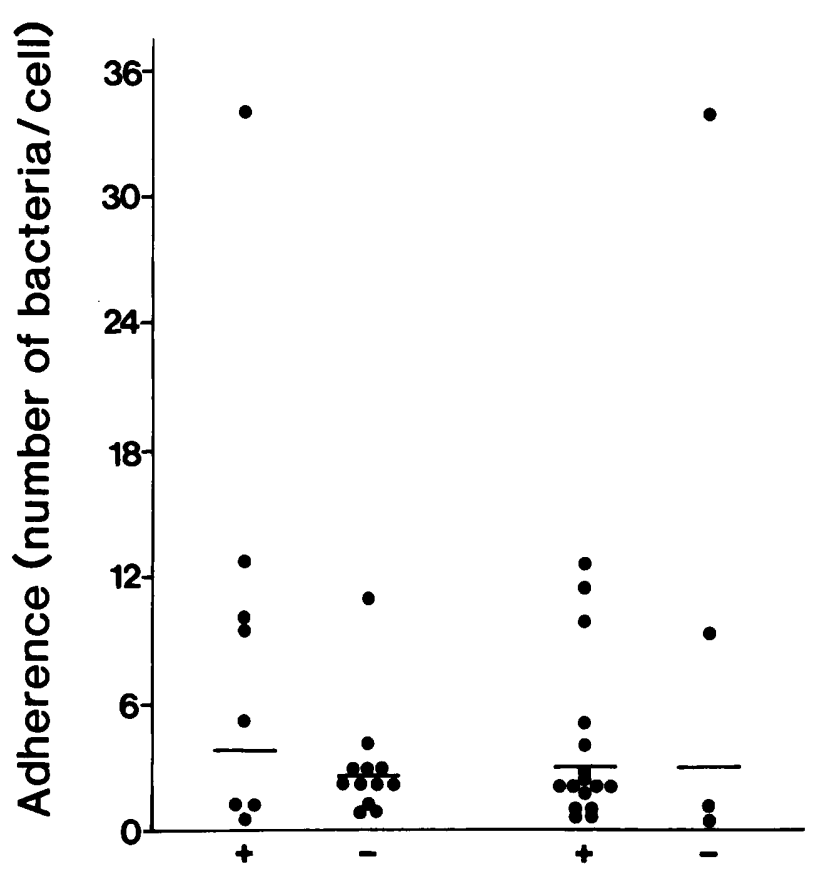

Fimbriae

Fig. 4. Quantitative adherence of VTEC to rabbit ileal cells as related to the presence of surface fimbriae and to hybridisation with the 3.4-kb DNA probe. Bars represent geometric means of each group. The differences among the groups were not significant by analysis of variance.

were determined. They included incubation for $45 \mathrm{~min}$ at $37^{\circ} \mathrm{C}$ and $\mathrm{pH} 7 \cdot 0$. Preliminary experiments showed that the adherence was maximal to intestinal cells obtained from the distal ileum or proximal colon. Further studies were conducted with cells from the distal ileum.

VTEC strains differed markedly in their adherence capability (table II). Binding to intestinal cells ranged between 0.3 and 34.0 bacteria/cell. The non-O157:H7 E. coli strain 43-12 (untypable:H21) showed the highest binding. Under the same growth and assay conditions, the adherence of the commensal E. coli strain HS was $2 \cdot 1$ bacteria/cell, i.e., higher than the binding of a few VTEC strains.

\section{Correlation between presence of fimbriae, hybridisation with the 3.4-kb probe and adherence}

The adherence of VTEC strains as related to these traits is shown in fig. 4. Strains with surface fimbriae showed a wide range of adherent capability. The geometric mean bacteria/intestinal cell of fimbriate strains was higher than that of the non-fimbriate strains (3.9 versus 2.7$)$, but there was overlap between the two groups and the difference was not statistically significant. The adherence of strains that hybridised with the $3 \cdot 4-\mathrm{kb}$ probe did not differ from that of strains that did not hybridise (geometric mean 3.1 bacteria/ cell for both groups). There were strains with no fimbriae (e.g., strain H30) or strains that did not hybridise with the probe (e.g., strain 43-12) that

showed high adherence (11.3 and 34.0 bacteria/cell. respectively).

\section{Discussion}

VTEC strains differed significantly in their ability to adhere to rabbit intestinal cells. In a quantitative assay, the differences among the various strains were marked, although the strains were grown under similar cultural conditions and studied simultaneously. The adherence of $E$. coli strain 43-12 (untypable: H21) was $>100$-fold higher than another VTEC strain, 3047-86 (O26:H11). Variability in adherence has been shown before in E. coli $0157: \mathrm{H} 7,{ }^{14}$ the prototype VTEC serotype, but not in non-O157:H7 strains. It remains to be determined whether the adherence properties of VTEC strains influence the clinical presentation of infection with regard to attack rate, development of bloody or non-bloody diarrhoea, or the rate of developing systemic complication, such as HUS. The adherence of VTEC strains with the lowest levels of binding was not distinct from that of a non-pathogenic, commensal E. coli strain HS.

It is obviously possible that after adherence to the intestinal mucosa, even in small numbers, VTEC strains, in contrast to commensal bacteria, could express other virulence traits such as cytotoxin production and thereby cause disease. Adherence may enable a more effective, local delivery of toxin. The relevant toxins have been shown to be capable of killing intestinal cells. ${ }^{2}$

This study also showed that neither the presence of surface fimbriae nor hybridisation with the $3 \cdot 4-\mathrm{kb}$ DNA probe derived from the presumed adherence plasmid was essential for adherence. Some strains that did not have fimbriae or did not hybridise with the probe adhered avidly. This is in agreement with the results of several studies. ${ }^{22,23}$ However, there was no single VTEC isolate that did not have one of these traits; all strains that gave negative results in the hybridisation assay had surface fimbriae. Thus, it is possible that several distinct adherence mechanisms are important in different VTEC strains.

Of the VTEC strains studied, all O157:H7 strains and c. $70 \%$ of the non-O157:H7 strains hybridised with the 3.4-kb DNA probe. Similarly, it had been reported previously that $99 \%$ of $0157: \mathrm{H} 7$ strains $^{20}$ and $79 \%^{20}$ or $65 \%^{18}$ of non-O157: $\mathrm{H} 7$ strains hybridised with this probe. The adherence characteristics of the strains were not determined in these studies. In the present study there was no difference in the adherence capability of strains that hybridised with this probe and those that did not. Some strains that had a very avid adherence, e.g., E. coli strain 43-12, did not hybridise with the probe.

Surface fimbriae were observed on $60 \%$ of the strains studied. Fimbriate strains adhered better as a group, although marked variability in the adherence of both fimbriate and non-fimbriate strains was noted. 
Summarising the data from several previous reports on surface properties of VTEC shows that about half of such strains were fimbriate. ${ }^{12,14-18}$

It has been suggested that the $60-\mathrm{MDa}$ plasmid encoded surface fimbriae that were important in adherence. ${ }^{12}$ From the present study we can conclude that the $3 \cdot 4-\mathrm{kb}$ probe derived from this plasmid is probably not related to the production of fimbriae, because strains that did not hybridise with the probe showed surface fimbriae and other strains hybridised but did not have fimbriae.

The relevance of these findings in animal models to the pathogenesis of human disease may be challenged. However, previous studies have shown that adherence of VTEC to rabbit enterocytes and brush borders did correlate with the binding to human enterocytes and that the binding was primarily to the apical membranes of rabbit enterocytes, rather than to basolateral surfaces. ${ }^{14}$ Inoculation of rabbits with VTEC strains has shown that these bacteria adhered in vivo to intestinal mucosal surfaces, causing damage to ileal brush borders, ${ }^{9,10,13}$ and the inoculated animals developed diarrhoea. Thus, rabbits seem to be an appropriate animal model to study the adherence of VTEC.

This work was presented in part at the Annual Meeting of the American Society for Microbiology, Anaheim, CA, in May 1990. We acknowledge grant support (HD-13021) from the National Institutes of Health, USA, and (90017) from the USA-Israel Binational Science Foundation.

\section{References}

1. Riley LW, Remis RS, Helgerson SD et al. Hemorrhagic colitis associated with a rare Escherichia coli serotype. $N$ Engl $J$ Med 1983; 308: 681-685.

2. Karmali MA. Infection by verocytotoxin-producing Escherichia coli. Clin Microbiol Rev 1989; 2: 15-38.

3. Cleary TG. Cytotoxin-producing Escherichia coli and the hemolytic uremic syndrome. Pediatr Clin North Am 1988; 35: 485-501.

4. Pai CH, Ahmed N, Lior H, Johnson WM, Simms HV, Woods DE. Epidemiology of sporadic diarrhea due to verocytotoxin-producing Escherichia coli: a two-year prospective study. J Infect Dis 1988; 157: 1054-1057.

5. Lopez EL, Diaz M, Grinstein S et al. Hemolytic uremic syndrome and diarrhea in Argentine children: the role of Shiga-like toxins. $J$ Infect Dis 1989; 160: 469-475.

6. Karmali MA, Petric M, Lim C, Fleming PC, Arbus GS, Lior H. The association between idiopathic hemolytic uremic syndrome and infection by Verotoxin-producing Escherichia coli. J Infect Dis 1985; 151 : 775-782.

7. Konowalchuk J, Speirs JI, Stavric S. Vero response to a cytotoxin of Escherichia coli. Infect Immun 1977; 18: 775-779.

8. Beachey EH. Bacterial adherence : adhesin-receptor interactions mediating the attachment of bacteria to mucosal surfaces. $J$ Infect Dis 1981; 143: 325-345.

9. Potter ME, Kaufmann AF, Thomason BM, Blake PA, Farmer JJ. Diarrhea due to Escherichia coli $\mathrm{O} 157: \mathrm{H7}$ in the infant rabbit. J Infect Dis 1985; 152: 1341-1343.

10. Pai CH, Kelly JK, Meyers GL. Experimental infection of infant rabbits with verotoxin-producing Escherichia coli. Infect Immun 1986; 51: 16-23.

11. Tzipori S, Wachsmuth IK, Chapman $\mathrm{C}$ et al. The pathogenesis of hemorrhagic colitis caused by Escherichia coli $0157: \mathrm{H} 7$ in gnotobiotic piglets. $J$ Infect Dis 1986; 154: 712-716.

12. Karch H, Heesemann J, Laufs R, O'Brien AD, Tacket CO, Levine MM. A plasmid of enterohemorrhagic Escherichia coli $0157: \mathrm{H} 7$ is required for expression of a new fimbrial antigen and for adhesion to epithelial cells. Infect Immun 1987 ; 55 : $455-461$.

13. Sherman $\mathbf{P}$, Soni $\mathbf{R}$, Karmali $\mathbf{M}$. Attaching and effacing adherence of vero cytotoxin-producing Escherichia coli to rabbit intestinal epithelium in vivo. Infect Immun 1988; 56: 756-761.

14. Durno C, Soni R, Sherman P. Adherence of verocytotoxinproducing Escherichia coli serotype 0157:H7 to isolated epithelial cells and brush border membranes in vitro: role of type 1 fimbriae (pili) as a bacterial adhesin expressed by strain CL-49. Clin Invest Med 1989; 12: 194-200.

15. Sherman P, Soni R, Petric M, Karmali M. Surface properties of the vero cytotoxin-producing Escherichia coli O157:H7 Infect Immun 1987; 55: 1824-1829.

16. Toth I, Cohen ML, Rumschlag HS et al. Influence of the 60 megadalton plasmid on adherence of Escherichia coli O157:H7 and genetic derivatives. Infect Immun 1990; 58: 1223-1231.

17. Sherman PM, Soni R. Adherence of Vero cytotoxin-producing Escherichia coli of serotype 0157:H7 to human epithelial cells in tissue culture: role of outer membranes as bacterial adhesins. J Med Microbiol 1988; 26: 11-17.

18. Dorn CR, Scotland SM, Smith HR, Willshaw GA, Rowe B. Properties of vero cytotoxin-producing Escherichia coli of human and animal origin belonging to serotypes other than O157:H7. Epidemiol Infect 1989; 103: 83-95.

19. Wadolkowski EA, Burris JA, O'Brien AD. Mouse model for colonization and disease caused by enterohemorrhagic Escherichia coli 0157:H7. Infect Immun 1990; 58: 2438-2445.

20. Levine MM, Xu J, Kaper JB et al. A DNA probe to identify enterohemorrhagic Escherichia coli of 0157:H7 and other serotypes that cause hemorrhagic colitis and hemolytic uremic syndrome. J Infect Dis 1987; 156: 175-182.

21. Junkins AD, Doyle MP. Comparison of adherence properties of Escherichia coli $0157: \mathrm{H} 7$ and a 60-megadalton plasmidcured derivative. Curr Microbiol 1989; 19: 21-27.

22. Tzipori S, Karch H, Wachsmuth KI et al. Role of a 60 megadalton plasmid and Shiga-like toxins in pathogenesis of infection caused by enterohemorrhagic Escherichia coli O157:H7 in gnotobiotic piglets. Infect Immun 1987; 55: 3117-3125.

23. Firon N, Ashkenazi S, Mirelman D, Ofek I, Sharon N. Aromatic alpha-glycosides of mannose are powerful inhibitors of the adherence of type 1 fimbriated Escherichia coli to yeast and intestinal epithelial cells. Infect Immun 1987; 55: $472-476$.

24. Ashkenazi S, May L, LaRocco M, Lopez EL, Cleary TG. The effect of postnatal age on the adherence of enterohemorrhagic Escherichia coli to rabbit intestinal cells. Pediatr Res 1991; 29: 14-19.

25. Whittam TS, Wachsmuth IK, Wilson RA. Genetic evidence of clonal descent of Escherichia coli $\mathrm{O} 157: \mathrm{H} 7$ associated with hemorrhagic colitis and hemolytic uremic syndrome. $J$ Infect Dis 1988; 157: 1124-1133.

26. Ashkenazi S, Cleary TG, Murray BE, Wanger A, Pickering LK. Quantitative analysis and partial characterization of cytotoxin production by Salmonella strains. Infect Immun 1988; 56: 3089-3094.

27. Newland JW, Neill RJ. DNA probes for Shiga-like toxins I and II and for toxin-converting bacteriophages. $J$ Clin Microbiol 1988; 26: 1292-1297.

28. Kado CI, Liu S-T. Rapid procedure for detection and isolation of large and small plasmids. $J$ Bacteriol 1981; 145: 1365-1373. 